\title{
Slab dehydration and magmatism in the Kurile arc as a function of depth: a multi-isotopic perspective
}

\author{
HONG-YAN LI ${ }^{1 *}$, JEFFREY G. RYAN ${ }^{2}$, CHAO XIE $^{1}$, XIANG
} $\mathrm{LI}^{1}$, RUI-PENG ZHAO ${ }^{1}$, YI-GANG XU ${ }^{1}$

${ }^{1}$ State Key Laboratory of Isotope Geochemistry, Guangzhou Institute of Geochemistry, Chinese Academy of Sciences, Guangzhou 510640, China. *hongyanli@gig.ac.cn

${ }^{2}$ School of Geosciences, University of South Florida, Tampa FL 33620, USA.

Dehydration of the subducting slab plays a critical role in the generation of volcanic arc lavas. Numerous studies have documented that the volcanic front lavas are more enriched in fluid mobile elements (e.g., B, Cs and Ba) than lavas erupted in the rear arc and back arc regions. One of the hottest debates centers on what these geochemical variations reveal about the slab dehydration process beneath the arc. A detailed study of across-arc geochemical variations in Quaternary volcanic rocks from the Kurile arc documents correlations among multiple isotopic tracers (B-Sr-Nd-Hf) and key elemental ratios $(\mathrm{B} / \mathrm{Nb}, \mathrm{Ba} / \mathrm{Nb}$, and $\mathrm{Th} / \mathrm{Nb})$ that show that these arc lavas reflect the influence of three components: lowtemperature $\mathrm{H}_{2} \mathrm{O}$-rich slab fluids (high $\mathrm{B} / \mathrm{Nb}, \mathrm{Ba} / \mathrm{Nb}$ and $\delta^{11} \mathrm{~B}$, and moderate $\mathrm{Th} / \mathrm{Nb}$ ), high temperature solute-rich slab fluids (moderate $\mathrm{B} / \mathrm{Nb}, \mathrm{Ba} / \mathrm{Nb}$, and $\delta^{11} \mathrm{~B}$ and high $\mathrm{Th} / \mathrm{Nb}$ ) and the ambient mantle (low in all these tracers). Rear arc lavas reflect a simple mixture of unmodified ambient mantle with solute-rich slab fluids. The mantle source of volcanic front lavas is more complex in that the lavas reflect mixtures of solute-rich fluids, the mantle, and $\mathrm{H}_{2} \mathrm{O}$-rich fluids, indicating a two-stage metasomatic process. Both the $\mathrm{H}_{2} \mathrm{O}$-rich and solute-rich fluids have similar radiogenic ${ }^{87} \mathrm{Sr} /{ }^{86} \mathrm{Sr}$, suggesting both fluids reflect the signature of altered oceanic crust and sediment on the downgoing slab.

These observations show that the chemical makeup of slab fluids is controlled by temperature during dehydration. Low-temperature, shallow-derived $\mathrm{H}_{2} \mathrm{O}$-rich fluids mobilize only strongly fluid mobile elements (e.g., B, Ba and $\mathrm{Sr}$ ), while high temperature, deeper, solute-rich fluids can also mobilize LREE (e.g., Nd) and Th. Progressive dehydration depletes the slab with depth, as demonstrated by low $\delta^{11} \mathrm{~B}$ over a range of $\mathrm{Sr}-\mathrm{Nd}$ isotopic signatures among the rear arc lavas. Sub-arc mantle convection plays an key role in the geochemistry of lavas in mature arcs, in that mantle metasomatized by deep-sourced, high solute fluids is metasomatized again by cooler, $\mathrm{H}_{2} \mathrm{O}$-rich fluids near the arc volcanic front. 